\title{
Why the Poles Collaborated So Little-And Why That Is No Reason for Nationalist Hubris
}

\author{
John Connelly
}

Klaus-Peter Friedrich asks why Poland has witnessed recurring debates about collaboration. My impression is the opposite: Poles do not consider collaboration in World War II to be a topic. ${ }^{1}$ On a visit to Warsaw several years ago I attempted to provoke historians in the Institute of Political Studies (Polish Academy of Sciences) by asking who among them was investigating Polish collaboration with the Nazis. Without permitting himself the briefest pause for reflection, one of the historians answered: "No one is working on that, because there was no collaboration."

Shortly thereafter the country was shaken when Jan Gross revealed that Poles had killed their Jewish neighbors in Jedwabne. Yet even this trauma to national memory did little to stimulate broader reflection on "Polish collaboration." One younger researcher, Anetta Rybicka, perhaps inspired by Gross, wrote a dissertation on what seemed a major case of treason of intellectuals, namely the Institut für deutsche Ostarbeit (Institute for German Eastern Work) in Kraków, which employed dozens of Poles in projects designed to strengthen Nazi views of Polish history and culture. Though her work did provoke a string of articles by leading scholars on "collaboration" (as well as a panel discussion in Kraków that Rybicka refused to attend) it has been largely rejected by the Polish historical community as unsound. ${ }^{2}$

Now Klaus-Peter Friedrich presents the most serious challenge to Polish wartime myths ever assembled, based on exhaustive research, including many little-known sources. He takes on a rather self-satisfied national narrative in a way that is hardly thinkable in Polish academia, identifies numerous weaknesses and exceptions, and pries open a historiography obsessed with martial minutiae and overgrown with easy assumptions about martyrology. ${ }^{3}$ Yet I am skeptical about its chances of shattering our

I would like to thank Mikolaj Kunicki for helpful comments.

1. See for example Andrzej Friszke's synthetic history, Polska: Losy panistwa i narodu 1939-1989 (Warsaw, 2003), which addresses only the issue of collaboration with Soviet occupiers in World War II. Tomasz Strzembosz's history of the Polish underground does touch upon collaboration with the Germans, but almost entirely by ethnic groups other than Poles. See his Rzeczpospolita podziemna: Spoteczeństwo polskie a państwo podziemne 19391945 (Warsaw, 2000), 88-130. Andrzej Paczkowski devotes several pages of his history of modern Poland to the subject of collaboration, which he views as having been marginal. Andrzej Paczkowski, Pót wieku dziejów Polski 1939-1989 (Warsaw, 1995), 40-45.

2. Anetta Rybicka, Instytut Niemieckiej Pracy Wschodniej, Institut für Deutsche Ostarbeit, Kraków 1940-1945 (Warsaw, 2002). See also the articles and interviews in Tygodnik Powszechny, nos. 21-27, 25 May-6 July 2003. Teresa Bałuk-Ulewiczowa has accused Rybicka of poor scholarship and plagiarism. See her Wyzzolic sięz btędnego kota: Institut für Deutsche Ostarbeit $w$ świetle dokumenlôw Armii Krajowej i materiatów zachozuanych w Polsce (Kraków, 2004).

3. Having learned much from Friedrich's work, I have actively encouraged him for years to present it to an English-speaking audience.

Slavic Review 64, no. 4 (Winter 2005) 
basic image of World War II in Poland. This image happens to be well grounded in fact: despite Friedrich's strictures, Poland remains a country without a Quisling and, in all of Nazi-controlled Europe, the place least likely to assist the German war effort.

Friedrich's case studies deserve careful attention and should inspire new research. But if one leaves the arena of Polish historiography one has to wonder: why should the fact that some Poles worked with the Germans surprise us? Did not the Germans find people willing to work with them in all the countries they controlled? Over three decades ago Stanley Hoffmann noted that the mere fact of German occupation necessitated some minimum of contact with the occupier. Problems of a moral nature began when one exceeded that minimum, doing more to further German war goals than the Germans themselves required, for example when the police of Vichy rounded up non-French Jews in the summer of 1942. ${ }^{4}$

Hoffmann coined a word to describe the crossing of that boundary: collaborationism. ${ }^{5}$ But that word has failed to gain wide currency. The reason is simple: beginning in the war years, the previously neutral word collaboration, signaling something like simple cooperation, shifted to connote treason. That is why the German historian Hans Lemberg asserted in 1971 that "everyone knows what collaboration means." Simply reading the morning newspaper he could register widespread agreement on the word's present-day meaning, for example in the "collaboration" of a recently unmasked political enemy in the People's Republic of China, or the "collaboration" of some Aztecs with the Conquistadors. ${ }^{6}$

Klaus-Peter Friedrich oscillates between the original meaning and the more recent connotation. At times, he specifies the sort of behavior considered treasonous, for example, assistance in ghetto clearing by construction squads or by Blue Police. But at times Poles are considered to have collaborated merely by virtue of holding certain positions. We learn, for example, that the number of employees in the administration increased over the course of the war. But do we think of French, Belgians, or Danes as having participated in collaboration merely for serving in the administration? Or would we judge Czech peasants as having "collaborated" because of assistance in the provision of natural produce? Ironically, Friedrich has met the megalomania of Polish nationalism on its own impossibly demanding terms.

Yet if one places Poland in the context of Nazi-occupied Europe, what stands out is the Germans' hesitance to involve Poles in acts of collaboration. Some Polish police were involved in ghetto clearing, but the Germans much preferred to use Baltic and Ukrainian forces. They hardly ever used Poles to help guard the camps they built on Polish soil. And if they forced thousands of young Poles into uniforms and armed them with spades in so-called construction battalions, elsewhere they formed SS

4. Philippe Burrin, France under the Germans: Collaboration and Compromise, trans. Janet Lloyd (New York, 1996), 156-57.

5. Stanley Hoffmann, "Collaborationism in France during World War II," Journal of Modern History 40, no. 3 (September 1968): 375-95.

6. Hans Lemberg, "Kollaboration in Europa mit dem Dritten Reich um das Jahr 1941," in Karl Bosl, ed., Das Jahr 1941 in der europäischen Politik (Munich, 1972), 143. 
units that attracted hundreds of thousands of volunteers from Ukraine, France, Holland, Denmark, Norway, Estonia, and Lithuania. As allies they counted Slovaks, Magyars, Croats, Romanians, Bulgarians, and Italians. Late in the war, the need for military collaborators grew so desperate that the Nazis even permitted Russians to join the fight on their side. Yet never did they extend such an invitation to the Poles. The question is, why not.

Many accounts allege that the Germans did not desire Polish collaboration because of their preset racial agenda in Poland. In the midst of the Jedwabne controversy, Abraham Brumberg wrote that "it was largely the German policy of unmitigated terror that caused Poles to refuse outright military collaboration." The implication is that Poles indeed would have collaborated had the Germans permitted them to. I disagree on this point. In fact, the Germans not only wanted Polish collaboration, they were counting on it. Before 1939 Nazi Germany envisioned Poland as an ally in the conquest of the Soviet Union. There is no hint in Nazi writings from before 1939 of some deeper ideological antipathy toward Poles that might explain the severity of Nazi occupation in Poland and the refusal to court collaborators. Poland appears marginally in Adolf Hitler's writings and speeches. Though he considered Poles "racially foreign elements," the Polish victory over the Soviet Union in 1920 had made it difficult for him to conceive of Polish racial inferiority. All of this goes against what has been suggested by authors as varied as Norman Davies, Jan Gross, and Jerzy W. Borejsza who have alleged a supposedly deep-seated Nazi antiPolonism or anti-Slavism. In fact, Nazi policies toward all Slavic groups were flexible and opportunistic. ${ }^{8}$

How then does one account for the fantastic brutality the Nazis unleashed in Poland in 1939? That had to do first of all with the Polish refusal to collaborate: the Polish government, with the overwhelming support of its population, steadfastly rebuffed German entreaties in late 1938 and early 1939. In addition to participation in the anti-Comintern pact, the Germans had demanded the city of Danzig and an extraterritorial highway and railway through Polish territory, linking the Reich with East Prussia. In return, they offered to guarantee Poland's borders and dangled a share of the spoils of war with the Soviet Union. Poland's leaders not only refused these proposals but also, to Hitler's outrage, they received promises of support from Great Britain in late March 1939, should Poland's sovereignty be "clearly threatened." The following month, Hitler renounced the pact of 1934 and began planning Poland's destruction.

There were, of course, deep sources in German culture to support the campaign of destruction launched upon Poland in September 1939. AntiPolish sentiments were especially strong in Prussia. But what triggered the violence was not a deeper Nazi ideological animus against Poles but Polish refusal to cooperate. It has been said many times before but bears repeating: Poland was the first country to say no to Hitler.

7. See his letter to the Times Literary Supplement, 27 April 2001.

8. That fact was reflected in the racial theories the Nazis supported before 1939. For an extended version of this argument, see my "Nazis and Slavs: From Racial Theory to Racist Practice," Central European History 32, no. 1 (1999): 1-33. 
I write all this not to salvage "Poland's reputation" but rather to highlight an understudied historical dynamic that explains the escalating cycles of violence in wartime Poland. Neither the Czech lands nor western Europe witnessed the extraordinary violence of the German attack on Poland; Warsaw was leveled for its defiance, while German troops marched into Prague or Paris without a shot fired. After the bloody beginning, the struggle in Poland against the Nazis never ceased. Soon after the capitulation of armies, conflict shifted to conspiratorial underground formations, and whenever open fighting was interrupted on one front-for example, when direct acts of violence became too costly-then it receded to others, preeminently sabotage and military intelligence, but also culture, including secret Polish-language plays, or the teaching of Polish literature and history in small conspiratorial classes. In Poland, the war did not cease after the German invasion, and therefore to speak of German occupation there is misleading.

If the extraordinary breadth of the Polish underground had no parallels in Nazi-controlled Europe that was in part because Poles were responding to the extraordinary determination of the Nazis to destroy them as a nation. For example, unlike Czechs, Poles were forbidden their own scholarly and scientific journals as well as schools above grade six. But the Polish response was also a legacy of previous generations who had fought for Polish culture in underground structures under the tsars and Prussians. The elders of 1940 had been the children of 1900. Czechs, who did not have this kind of heritage, never set up underground university courses after the Nazis closed universities in the "Protectorate" in November 1939.

The unique situation in Poland was reflected in language. Poles spoke not of "collaboration," or "resistance" but rather - as befitted people living in a state of war - of "treason" on the one hand and of "underground" or "conspiracy" on the other. ${ }^{9}$ Treason, of course, is a crime of state, and therefore the Polish underground state included tribunals that passed sentences on Poles who helped the enemy.

These basic facts are not new, but I think they should precede any discussion of collaboration in Poland for all but specialist audiences. When Klaus-Peter Friedrich writes about the percentage of Polish mayors in the Generalgouvernement, most readers are unlikely to know that Poles were denied independent administration above the level of the village. Germans controlled the four district administrations they created in the Generalgouvernement as well as the administration of the cities and larger towns. There was no Polish administration whatsoever in the vast areas of Poland annexed to Germany or the Soviet Union. All of this stood in radical contrast to the situation in the Protectorate of Bohemia and Moravia, not to mention France or Belgium.

9. Czesław Madajczyk, "Zwischen neutraler Zusammenarbeit der Bevölkerung okkupierter Gebiete und Kollaboration mit den Deutschen," in Werner Röhr, ed., Okkupation und Kollaboration (1939-1945): Beiträge zu Konzepten und Praxis der Kollaboration in der deutschen Okkupationspolitik (Berlin, 1994), 49. 
To foreground the unique dynamic of Polish-German conflict in World War II also fosters dispassionate discussion of collaboration, a subject that seems inextricably linked to narratives of national virtue-or the lack thereof. If advocates of a Polish national narrative become exasperated over their critics' ignorance of basic facts, critics often suspect nationally minded Poles of trying to fabricate a narrative of heroism that then translates into national pride. And they have an excellent point. When historians allege that their research boosts group pride, then readers have a right to suspect blind spots, such as Jedwabne-known about for decades, yet shrouded in ignorance as the supposed exception that proved the rule. ${ }^{10}$

In other words, dispassion is important because skeptics fear that by recognizing Poland's wartime record of apparently unusual virtue they are bolstering Polish nationalism. That fear is ungrounded. When one views the matter sine ira et studio, one sees that Poles of an earlier generation refused to collaborate not because of collective attachment to virtues like personal freedom or liberal democracy but rather out of a supreme devotion to Polish sovereignty - understood to include culture - that made compromises painful to countenance, both for elites and the broad masses. That explains the extraordinary clash of September 1939, in which any neutral observer would have recommended capitulation. In the conflict that ensued, countless Polish citizens displayed awe-inspiring courage. But in any people there are also those who seek personal advantage in times of group calamity. If such individuals in Poland proved less likely to collaborate with the Nazis than counterparts elsewhere that was because they knew they would be punished by fellow countrymen.

Poles thus endured the war suspended between the demands of two institutions claiming authority: one German and one Polish. The resulting tensions are readily seen in the operations of the Polish Blue Police. The Germans did not trust them and therefore denied them higher ranks and kept them under close supervision. But these policemen also lived in Polish society, and the tentacles of underground conspiracy reached into their very families. Some estimates place the number of policeman collaborating with the Home Army as high as $\mathbf{5 0}$ percent."

Another case in which one sees this logic at work is the Institut für Deutsche Ostarbeit mentioned above. Believing she had stumbled upon a suppressed story of collaboration, Anetta Rybicka neither consulted the employees of this organization who were still alive nor looked at records of the Home Army. It turns out that leading "collaborator" Professor

10. Jan Gross's major critic in the Jedwabne controversy, Tomasz Strzembosz, concluded his history of the Polish underground with the words: "We may be proud of the Polish Underground State of the years 1939-1945." Strzembosz, Rzeczpospolita podziemna, 323.

11. Adam Hempel, Pogrobowcy kleski: Rzecz o policji "granatowej" w Generalnym Gubernatorstuie 1939-1945 (Warsaw, 1990), 217-18. In August 1939, the total number of Polish uniformed police on the territories that became the Generalgouvernment was 9,794. Other European countries had twice to four times as many police per capita (with the exception of Sweden). In 1942 the Blue Police numbered 11,500. Ibid., 25, 92. 
Mieczysław Malecki was in fact the chief organizer of the underground university in Kraków during the war, responsible for dozens of courses taught in complete secrecy from the Germans in private apartments across the city, needless to say at extraordinary personal risk. Malecki was operating with the blessings of underground structures in Kraków, which agreed to "supervise" work at the Institut because that permitted Poles to utilize and help protect the confiscated rooms and equipment of Jagiellonian University, which was closed in 1939 after its professors were sent to Oranienburg. Malecki's position of course provided excellent "cover." And far from the dozens of professors referred to in sensationalist press reviews of Rybicka's book, the Institut employed only six Polish professors. That is not many in a city with three institutions of higher education.

A further test of the underground state's power to enforce proper behavior is found in recent work by Martin Dean and Timothy Snyder on areas poorly controlled by that state in eastern Galicia and Volhynia. Limited research suggests that in these areas Poles were far more willing to collaborate in German institutions, including armed formations. ${ }^{12}$ Though poorly studied, the little that is known about former Polish areas further west, for example in the "Warthegau" or in Silesia, would seem to bear out similar conclusions: willingness to cooperate, for example by accepting German nationality (via the Volksliste), entering German organizations, and the like.

Of course, in both east and west such steps toward cooperation with the enemy were often taken under duress, either for protection from other forces (like Ukrainian nationalists in Volhynia), or to avoid arrest and deportation. Yet if it is understood to approximate a crime, then the question of intentionality should feature centrally in any discussion of collaboration. ${ }^{13}$ The information we presently possess on the Volkslisten is hardly dense enough to permit clear judgment. We know that practice varied widely by region, most opportunistic in Silesia and Pomerania, much less so in the "Warthegau." ${ }^{4}$ Similarly, the degree of free will involved when "construction squads" assisted in executions or the clearing of ghettos is unknown. According to physician and Holocaust survivor Ludwik Hirszfeld, one young Pole who refused to take part in executions was shot in the head; likewise, former Baudienst conscripts interviewed in the 1970 s recalled that a number of comrades who could not bear working at execution sites were themselves "shot on the spot." These stories

12. Martin Dean, "Polen in der einheimischen Hilfspolizei: Ein Aspekt der Besatzungsrealität in den deutsch besetzten ostpolnischen Gebieten," in Bernhard Chiari, ed., Die polnische Heimatarmee: Geschichte und Mythos der Armia Krajowa seit dem Zxueitem Weltkrieg (Munich, 2003), 355-68; Timothy Snyder, "The Causes of Ukrainian-Polish Ethnic Cleansing 1943," Past and Present, no. 179 (2003): 197-234.

13. Hoffmann stresses the "deliberate" and Paczkowski the "active and conscious" nature of collaboration. Hoffmann, "Collaborationism," 379; Paczkowski, Pót wieku, 41.

14. In the former two provinces, tens of thousands of Poles were forcibly signed into the lower classes of the Volkslisten and then forced to assume the privileges and burdens of being "German." Tens of thousands of the Poles of these regions who were enlisted in the Wehrmacht defected and served with Polish forces in the west. Friszke, Polska, 20. 
cast doubt upon Jan Gross's claim that the Germans "did not compel the local population to participate directly in the murder of the Jews." 15

If Klaus-Peter Friedrich's point is to enlighten those holding contrary views, he might have dwelt at greater length upon such nuances. Greater balance might also be registered in his discussion of the Polish peasantry. Did peasants really gain from the war? No doubt some did enrich themselves relative to other Poles, but at the same time the Germans destroyed over 650 villages, forced hundreds of thousands of peasants into slave labor in Germany, killed more hundreds of thousands outright, and devastated Polish agriculture. ${ }^{16}$ Overall, peasants were "relative winners" only in the sense that they were less likely to die than other groups of the population. But propensity to survive is not the same as propensity to collaborate.

Similar points might be made of denunciation. Friedrich terms it a "widespread phenomenon" based upon a book examining 255 letters to the Gestapo from the Warsaw district early in the war. In fact, this book only underscores the uncanny powers of the Polish underground and its deep support in Polish society: though the full extent of denunciations made during the war remains unknown, researchers have determined that Polish postal workers routinely intercepted letters addressed to the Gestapo from the Polish population. ${ }^{17}$ As a result, the Germans rarely penetrated the underground's shell. Of the tens of thousands of illegal university course meetings that took place from 1940-45, for example, only one was discovered by the Gestapo, and that by accident. ${ }^{18}$

15. See my "Poles and Jews in the Second World War: The Revisions of Jan T. Gross," Contemporary European History 11, no. 4 (2002): 652.

16. Kazimierz Przybysz, Chtopi polscy wobec okupacji hitlerowskiej 1939-1945: Zachowvania i postauy polityczne na terenach Generalnego Gubernatorstzua (Warsaw, 1983), 47-59. Przybysz writes that $1,272,000$ inhabitants of villages lost their lives and 153,000 suffered injuries leading to permanent invalidism during the war (73). He does not break down population by ethnicity. In contrast to Friedrich, Przybysz emphasizes Home Army reports noting the "patriotic and oppositional posture" of Polish peasants (111). Friedrich also provides a distinctly uncharitable reading of Wacław Dlugoborski, who writes that the forty thousand employees of cooperatives were "mostly honest and patriotic," and that "in the second half of the war, as the resistance gained in strength in the countryside as well and announced warnings and even death sentences against dishonest employees, most of them stopped taking advantage of the occupiers at the expense of other Poles. It was also possible to smuggle many honest, patriotically minded Poles into the administration." Dhugoborski writes that the peasants "did relatively well" at a time when "the entire nation became impoverished." In other words, they were less impoverished than other Poles but shared in the general decline in standards of living. Waclaw Długoborski, "Die deutsche Besatzungspolitik und die Veränderungen der sozialen Struktur Polens 1939-1945," in Waclaw Długoborski, ed., Zzueiter Welthrieg und sozialer Wandel: Achsenmächte und besetzle Länder (Göttingen, 1981), 324, 352, 360.

17. Barbara Engelking, "Szanowny panie gistapo": Donosy do wtadz niemieckich wo Warszawie i okolicach w latach 1940-1941 (Warsaw, 2003), 20-23.

18. The participants, engaged in a seminar in sociology, were executed. See my Caplive University: The Sovietization of East German, Czech, and Polish Higher Education, 1945-1956 (Chapel Hill, 2000), 87. Włodzimierz Borodziej writes that the "number and role of denunciations, being a specific social reaction to the chaos of the first years of occupation, in the course of time were subject to serious reduction: occupation policies without doubt 
There is also the more general methodological question of what to make of the sentences passed by the underground on collaborators. The leading expert estimates their number at seventeen thousand (among some 11 million ethnic Poles), and calls the phenomenon of collaboration "marginal." 19 Using the same information, Friedrich reaches the opposite conclusion.

As intimated above, I do not believe that Klaus-Peter Friedrich's valuable piece gives us reason to abandon existing views of Polish collaboration. His case studies show that only relatively small percentages of the Polish population engaged in activities that might be described as collaboration when seen against the background of European and world history. More importantly - to speak in the language of the detective storyFriedrich fails to deliver a motive for the "crime" he alleges. In his 1979 monograph, Jan Gross wrote that the Germans' random application of terror and the resulting unpredictability of daily existence gave little incentive for legal, cooperative behavior among Poles and tended to propel them into the underground. ${ }^{20}$ They had little to lose. Friedrich's work does not contradict this basic model. When one extends one's view to the underground state's courts, the incentive to collaborate appears even more mysterious: collaborators made themselves targets of retribution. If even Germans dreaded the death sentences of the Polish undergroundin 1943, for example, the German director of the Landeswirtschaftsbank (Agricultural bank) in Warsaw hurriedly fled Poland after such a sentence was passed-how much greater must the fear have been among Poles, whose protection under German law was exiguous? ${ }^{21}$

Despite these criticisms, I believe that Klaus-Peter Friedrich has made an invaluable contribution to the literature on Poland during World War II. Above all, he has suggested numerous avenues of research into forms of behavior about which remarkably little is known. Whether or not these forms constituted collaboration can be debated. How much power indeed resided in village councils, for example, to select conscripts for labor in Germany or to exempt the produce of certain farmers from compulsory delivery? How did this practice differ by region and by period? What in fact was the role of the Poles who served under Germans in the vast city administrations? In his first book Jan Gross praised "the high quality and professional expertise" and "certain degree of independence" of Poles working in these administrations, but the subject has not received

stimulated a growth of feelings of solidarity, and the massive terror eliminated any hope of 'limited stability,' and necessitated above all national integration." Włodzimierz Borodziej, Terror i polityka: Policja niemiecka a polski ruch oporu wo GG 1939-1944 (Warsaw, 1985), 85.

19. Leszek Gondek, Polska karczaca 1939-1945 (Warsaw, 1988), 144-45.

20. Jan Gross, Polish Society under German Occupation: The Generalgouvernement 19391944 (Princeton, 1979), 238 and passim.

21. According to a note taken by an official of the Deutsche Bank who was employed in Poland during the war, "Experience shows that we must reckon with the execution of such sentences." Notiz, 8 October 1943, Historisches Archiv der Deutschen Bank, Frankfurt am Main, V2/1. I thank my colleague Gerald D. Feldman for this reference. 
systematic study. ${ }^{22}$ The generalizations that exist on the Blue Police, the construction battalions, or the Volkslisten are also based on a remarkably thin source base. Several authors cite the same single statistical table in the now dated work of Czesław Madajczyk. We also continue to know remarkably little about the thorniest of all issues in recent Polish history, namely Polish complicity in the Holocaust of Jews.

Polish historiography has hesitated to view such complicity as collaboration. Leading contemporary historian Andrzej Paczkowski, for example, considers extortion of Jews under threat of denunciation (szmalcownictwo) not as collaboration but rather as a form of society's "demoralization." For him, collaboration was the "active and conscious participation in activities aimed at the subjugation [zniewolenie] of Polish society." ${ }^{23}$ The implication is that to assist in the murder of Jews was not to aid in the subjugation of Polish society. In his first monograph, Jan Gross also bracketed Polish from Jewish experience, arguing that the Nazis had treated the groups very differently. ${ }^{24}$ To raise the question of whether and how Poles collaborated in the Holocaust thus involves the challenge of bringing two disparate historiographies into one frame of reference. ${ }^{25}$ This challenge also features a moral aspect: how does one combine the heroic (and true) tale of Polish resistance with the disturbing (and true) tale of Polish accommodation to the slaughter of the Jews?

Perhaps these Polish and Jewish stories will remain as far apart in the writings of historians as they were in the experiences of contemporaries. But Stanley Hoffmann's classic essay suggests how they might be joined at the point of complicity in the Shoah. He writes that collaboration (or, as he says, "collaborationism") was "deliberate service of the enemy." ${ }^{26}$ Yet acts of deliberate service by Poles did not figure in the primary methods of destruction of the Jews. In the overwhelming majority of cases, Jews were plunged into the machinery of destruction without a direct Polish role: they entered ghettos and then later transports on the pain of death enforced by the Germans. Where Poles became essential to the killing, however, was in identifying Jews who tried to escape destruction under the guise of "Aryans."

To say the least, Jews who escaped the ghettos were not shown the solidarity Poles expected from Poles. A particularly wrenching incident is recalled by Adam Neuman-Nowicki, a Polish Jew of impeccable "Aryan" ap-

22. Gross, Polish Society, 138. The huge Warsaw administration oversaw the running of illegal Polish education. Czesław Madajczyk, Polityka III Rzeszy w okupowanej Polsce, 2 vols. (Warsaw, 1970), 1:218-19.

23. Paczkowski, Pót wieku, 41, 44

24. The Polish underground did pursue so-called extortionists, but generally defined improper behavior toward the occupier in terms of the interests of the "Polish nation," which tended to be understood in ethnic terms. See the "Precepts" for a "moral order" in Gondek, Polska karczaca, 66-67.

25. To get a full sense of that challenge, one should compare the most recent work of Jan Gross with his early work. If he once analyzed Polish society at war with a romantically tinged fascination, he now subjects it to intense and often bitter criticism.

26. Hoffmann, "Collaborationism," 379. 
pearance and speech. At one point in his own ordeal as "Polish Christian," Neuman-Nowicki met the fellow Jew Hanka, with "blue eyes, straight blond hair combed into two braids, a small nose, and rosy cheeks." Having escaped deportation, she worked as a maid, but because she grew up speaking Yiddish, her Polish was not as "accent-free and polished" as was his. This small "flaw" proved her undoing: after a failed rendezvous, he discovered that she had been turned over to the German police. Of course, any sudden newcomer to a small town will be a subject of rumors, yet had this woman been a Pole, locals would have colluded in shielding her from danger. But as a Jew, Hanka was viewed as a curiosity, a welcome occasion for gossip. Before long the fatal rumor, spread carelessly, had reached the ears of an informer. ${ }^{27}$

The callous participants in such rumor mills would have been surprised to learn that they had deliberately served the enemy. The theologically minded might accuse them of grave "sins of omission," but even the underground courts would have been hard-pressed to arraign any but the individual who actually tipped off the Germans. Yet if no individual Pole can be held guilty of the crime, as a community Poles certainly can be accused of shared indifference, of what one might call a "structural collaboration" that made the Nazi agenda of killing Polish Jews so infernally successful. Had Poles indeed seen Jews as neighbors, the death rate might have been more like 85 percent rather than the 90 percent that was actually achieved. ${ }^{28}$

It should be noted that very little collaboration was needed to doom a Jew in hiding; all that was required was one actual informer among many thousands of Poles. On the opposite end, active, potentially selfsacrificing cooperation of scores of Poles was required to save that single Jew. Such odds were implicit in the killing structures created by the Nazis. The point was to reward base impulses beyond all measure but to require extraordinary sacrifice to produce simple virtue. The odds were so generally understood that even Poles motivated to assist Jews thought the enterprise foolhardy. They were also constrained by a popular discourse that alleged, "to help Jews is to endanger "us.'" 29

27. See Adam Neuman-Nowicki, Struggle for Life during the Nazi Occupation of Poland, ed. and trans. Sharon Stambovsky Strosberg (Lewiston, N.Y., 1998), 62-64. On the difficulties faced by Jews who attempted to hide among Poles, see also Jan Gross, "A Tangled Web," in István Deák, Jan T. Gross, and Tony Judt, eds., The Politics of Retribution in Europe: World War II and Its Aftermath (Princeton, 2000), 84-87.

28. Polish historians estimate that at most forty thousand Polish Jews were saved by non-Jews during the war, while some sixty thousand more survived in camps. Another two hundred thousand survived beyond the reach of the Germans in Soviet exile. The prewar total was some three million. Paczkowski, Pót wieku, 39; Friszke, Polska, 43.

29. For a compelling discussion of Poles' attitudes toward Jews in hiding, see Jan T. Gross, Neighbors: The Destruction of the Jetwish Community in Jedwabne, Poland (Princeton, 2001), esp. 152-61. On the thousands of Poles who made their livelihoods blackmailing Jews in wartime Warsaw, see Jan Grabowski, "Ja tego Żyda znam!": Szantazozvanie Żdów w Warszatvie, 1939-1943 (Warsaw, 2004). For the large number of Poles who also shielded Jews in wartime Warsaw, see Gunnar S. Paulsson, Secret City: The Hidden Jews of Warsatw, 1940-45 (New Haven, 2002). 
Klaus-Peter Friedrich also takes up an additional form of "structural collaboration" in Poland, namely Polish willingness to assume living quarters and personal property left behind by Jews. Even after the Germans had skimmed off the most valuable resources, Poles still seized the household and business possessions of millions of murdered Jewish neighbors. Though the issue has failed to attract the major study it deserves, it seems justified to state that before embarking on death transports Poland's Jews had performed one more service to a fatherland they had enriched for generations with contributions to culture, science, economy, and politics: they had bequeathed a wealth that kept tens, perhaps hundreds of thousands of fellow Polish citizens from starvation under a tremendously destructive German agriculture regime. ${ }^{30}$ At the level of social history, then, the history of Poles and Jews in World War II cannot be separated.

If Klaus-Peter Friedrich shows that Polish historiography is only enriched when confronted with the toughest of questions, then Jeffrey W. Jones suggests where that historiography might go in an increasingly postnational age. Friedrich's at times harsh judgments of the Polish Church or peasantry reflect his extraordinary knowledge of Polish underground publications. Their high standards for proper behavior have in a sense become his. But as Jones shows, the Soviet context was if anything more demanding: there, merely to have lived under German rule was to invite charges of collaboration. Why? Do we have here prima facie evidence of the difference between totalitarian and other societies? Or was the Russian discourse itself simply more constraining?

Even if "everyone knows what collaboration means," its exact meaning always depends upon historic context. And only when we juxtapose two or more cases-Poland and France, Poland and the Soviet Union-do we really learn what it was to collaborate in any specific place. Perhaps there will be recurring debates on collaboration in Poland, but they will lead to deeper understanding only when they look beyond Poland.

30. The Germans attempted to sever connections between city and land and, for anything beyond starvation rations, made Poles dependent upon the black market (Schleichhandel). They estimated that half the Polish population required the black market in order to get enough food to stay alive. Madajczyk, Polityka III Rzeszy, 1:596-97. 